\title{
African Ethnobotany in the Americas
}

Edited by Robert Voeks and John Rashford. 2013. Springer. Pp. 429, 105 illustrations, 69 color illustrations. \$49.95 (paperback). ISBN 978-1461408352.

Reviewed by Egleé L. Zent

Reviewer address: Lab Ecología Humana, IVIC, Altos de Pipe, Venezuela

Received: September 9, 2013

Volume: 4:107-109

Published: October 13, 2013

(C) 2013 Society of Ethnobiology

Fourteen chapters written by 19 scholars constitute African Ethnobotany in the Americas, a book that unlocks the radical consequences of politically and economically coerced movements of people and plants worldwide in diachronic perspective. This guiding purpose articulates distinctly with other books that do not specifically address plants, such as Mobility and Migration in Indigenous Amaronia (Alexiades 2009) and Women and Plants (Howard 2003). The first book emphasizes the agency of Amerindian peoples in the configuration of the natural and cultural landscape of the Amazon. The authors of the second book declare the fallacy of a gender neutral ethnobotany. In the same spirit, the authors of African Ethnobotany in the Americas recognize African people's central place in the history of the Americas. The book's authors represent African peoples and their descendants as meaningful agents in the management of botanical resources. By merging qualitative and quantitative approaches with rigorous data and first hand fieldwork, they demonstrate the explanatory power of research about people-plant interactions. This compendium of studies makes an explosive statement against decontextualized, ahistorical research that disregards African plants and people in the overall current configuration of the Americas.

The authors of this book use historical perspectives to effectively understand and explain multiple spheres of relationships between plants and peoples. The book is divided into sections about crops, handicrafts, medicine, permanence, and change in contemporary Caribbean (Cuba, Barbados), South American (Brazil, Ecuador, Suriname), and North American (United States) countries.

Judith Carney, Stanley Alpern, and Dorothea Bedigian discuss the importance of African crops in commerce, nutrition, social relations, and knowledge.
American agricultural systems received prominent inputs from Africa in terms of botanical species and human agency, as Carney points out. Twenty-six crops native to or introduced from Africa (millet, sorghum, rice, yams, plantains, black-eyed peas, watermelon, etc.) influence people's lives globally. The impact of rice is unquestionable, as Alpern demonstrates in a meticulous analysis of Africans' roles in the $18^{\text {th }}$ century South Carolina rice boom. The disputable Asian origin of rice is carefully discussed. Alpern substantiates how some rice species - prominently Oryza glaberrima Steud. Poaceae - was independently domesticated in Western Africa and, along with O. sativa L. Poaceae, entered the Americas with slaves. Elaborate knowledge about growing, processing, cooking, and re-producing rice by Africans is reported in detail.

Bedigian offers a thorough study of sesame (Sesamum indicum L. Pedaliaceae) in the Americas. In the book's longest chapter, she stresses biocultural (ecological, economic, geographical, historical) aspects of sesame as a crop that was first introduced to Africa and then to the Americas. Bedigian provides lengthy yet meticulously detailed accounts of sesame in different historical periods and geographical contexts (Eurasia and the Americas) from 1350 B.C.E. to the present, along with the diversity of use patterns (medicine, food, supernatural, punishment, etc.), names (vanglo, bowangala, etc.), and management domains (recipes, gardens, commercial).

The involvement of wild plants in the dynamics of slavery and freedom from past to present is nicely depicted by four authors. Dale Rosengarten renders a well-documented historical narrative of coiled basketry, which he represents as an eclectic, unique craft that changed because of the encounter between different African traditions in the Carolinas and the 
expansion of the craft to other Southern states (Georgia, Florida, Alabama, Mississippi) and overseas (Bermuda, Caicos Islands). African-descent slaves were responsible for creating the creole basket tradition and since baskets were utilized as receptacles for storing harvested rice grains, those slaves who had the skills to make these baskets were more valuable than others. The author identifies about two dozen plants found in the Carolina Lowcountry that were used for this purpose [Spartina alterniflora Loisel. Poaceae, S. patens (Aiton) Muhl. Poaceae, Juncus roemerianus Scheele Juncaceae, Juniperus virginiana Small Cupressaceae), Quercus virginiana Mill. Fagaceae, Sabal palmetto Walter Arecaceae, etc.]. Notably, baskets were agents of slaves' freedom and escape as reported by several factual cases. Basket making survived as an economic activity after slaves became freed.

Even today, Lowcountry South Carolinians make baskets, according to Patrick Hurley, Brian Grabbatin, Cari Goetcheus, and Angela Halfacre. Basket makers today gather, buy, and grow four local species [Mublenbergia sericeae (Michx.) P.M. Peterson Poaceae, Pinus palustris P. Mill Pinaceae, Juncus roemerianus G. Scheele Jucaceae and S. palmetto], to weave and sell baskets. The settings where the actual collections occur, however, are undergoing urbanization that disturbs traditional patterns of political-ecological and social dynamics associated with this craft. Land development patterns, private property, and habitat disturbance alter not just the social networks by which raw resource are accessed but also mark the potential termination of a non-timber forest product tradition (NTFPt) that has survived 400 years. This study warns planners and policy makers about the precarious survivability of sense of place and identity in a changing landscape.

Maria Fadiman proficiently discusses the economic, cultural, and conservation aspects of piquigua (Heteropsis ecuadorensis Kunth Araceae) in the ecological reserve Mache-Chindul on Ecuador's Pacific Ecuadorian coast. The minor economic importance of piquigua contrasts with its great cultural value for African-Ecuadorians, which in turn duplicate its potential significance in conservation as a NTFPt. Fadiman describes the historical arrival of black people to Esmeraldas in the $16^{\text {th }}$ century as escaped slaves who mixed with local indigenous populations, and later became a free creole community. Considering piquigua as a cultural keystone species, she details the different steps associated with collecting, prepar- ing, managing, weaving, marketing, and bartering piquigua by current descendants of African people.

A rich diachronic interpretation by James Sera and Robert Voeks acutely exposes the botanical and cultural foundation, construction, establishment, commercialization, and development of the berimbau de barriga, a one-stringed musical bow of West African origin in Brazil. Except for a metal wire ring, the berimbau is completely fabricated with wild and cultivated local plants (Lagenaria siceraria Standl. Cucurbitaceae, Heliconia sp. Heliconiaceae, Eschweilera ovata Miers Lecythidaceae, Coix lacryma-jobi L. Poaceae, etc.). The berimban accompanies capoeira where it condenses the dynamics of resistance and resilience that endured the colonial, republican and current periods for Afro-Brazilians. A creative result of the vast trading network of information, service, and goods among West Africa, Portugal, and Brazil, the berimbau materializes hegemony and symbolizes continuity and adjustment.

Three papers assert the impact of African spiritual and medicinal ethnofloras in American territories. Erica Moret establishes a comparison between botanical-use knowledge of migrants from two continents in Cuba organized around different agricultural systems: one based on tobacco usually attended by Hispanic descendants, and the other based on sugarcane whose workforce was mainly African peoples. Remarkably, Nicotiana tabacum L. Solanaceae is an American domesticate whereas Saccharum offinarum L. Poaceae is a crop introduced from Eurasia. Following a careful methodology, Moret studied 64 plants (46 originating from African centers and 27 from Mediterranean ones, while 9 are shared between the two regions) and uses her analysis of them to ponder power, identity, and resource access. Her data indicate a stronger botanical knowledge of West African plants in the sugar cultivation area whereas the Mediterranean-derived lore appears more widespread in both areas and is slightly higher in the tobacco zone. One-thousand one hundred botanical recipes using 411 sacred plant species (114 families) in the Afro-Surinamese Winti rituals are meticulously reported by Tinde van Andel, Sofie Ruysschaert, Koebeke Van de Putte, and Sara Groenendijk after interviewing 20 priests, along with several traditional healers, vendors and plant collectors. The authors are interested in ascertaining how and why those particular plants attain the role of magical icons after Africans arrived on American 
shores. Winti, a religion prohibited until the 1980s, conceals syncretic and identity dimensions bound to a wealth of ecological, botanical, historical, linguistic, and cultural wisdom that make specific plants sacred. The authors provided data associated with emic categories of 13 magical uses, management, and growth form of wild and domesticated species, vegetation type, flora attributes associated with rituals (color, scent, etc.), Signatures' Doctrine, and the ways in which plants aided African descendants in their struggle for self-determination. In Barbados, 93 medicinal species (31 used as cooling teas) were reported by 440 interviewees to Sonia Peter, a meaningful number given that less than 300,000 people live on the island. Peter studied 8 parishes and found women to be the major repositories of botanical knowledge. In her chapters, she presents phytochemical data on bioactive components of plants used as medicine by Barbados' people, whose country is rated as second in centenarians per capita.

The last section of the book comprises three chapters dedicated to current dynamics of continuity and change. John Rashford presents his detailed research on five species of Ficus spp. Moraceae that serve in Candomblé as cosmic trees, opposing the general assumption that one single species function for that purpose in Brazil. A detailed description of the importance of Ficus in Candomble is reported for 17 of the 19 terreiros (religious centers) where native and exotic Ficus are found. A more extensive exploration would probably yield more species, according to Rashford.

Bruce Hoffman provides a fascinating comparative ethnobotanical study between native indigenous people and Afro descendant communities in Suriname, the Trio, and the Saramacca. He uses comprehensive phyto-ecological and quantitative ethnobotanical methods to record botanical and ecological data along with knowledge, categorization, use, and resource selection of three tropical forest vegetation zones by 4 male specialists in each group (one Trio male left the community before the study ended). Hoffman presents different sections and results on biophysical characters, ecological features, and biodiversity use categories (examples of resource use patterns for 4 botanical families) by the Surinamese. One conclusion as predicted by the literature is that longer-term residents such as indigenous peoples have more extensive botanical knowledge than shorterterm residents although the latter are able to build a solid use-knowledge of local plants. Whereas the Trio show considerable knowledge in all vegetation zones, the Saramacca seem to have, quantitatively and qualitatively, a special interaction with fallow forest. The Saramacca also maintain a complex religious system that proscribes the use of old growth forest, thus proposing alternatives for culturally appropriated in situ conservation. Hoffman's chapter is from my view the most accomplished in the book.

Robert Voeks closes the book by describing the reassembling of African beliefs in Brazilian's Candomblé around a cornucopia of medicinal and edible plants related to particular orixás, or deities. Voeks confirms how the enslaved Africans innovatively used the landscapes that had become floristically similar to African ones because of the previous establishment of Old World esculent and medicinal plants. Accidental or voluntary introduction of plants by European migrants created anthropogenic settings in tropical America that appeared similar to the enslaved Africans' homelands that ended up in a process of botanical homogenization facilitating ethnobotanical continuity as well as resistance to the forced newcomers.

This fascinating book, written by inquisitive authors, should be required reading for ethnoecological scholars. It documents the essential importance of African peoples and plants in the Americas through fruitful methodological syntheses of ethnobotanical and ethnoecological approaches, both diachronic and synchronic. The sophisticated, quantitative methods of some chapters (Hoffman, van Andel et al., Hurley et al, Peter, Fadiman) are balanced by the meticulous, qualitative, detail-driven historical and ethnohistorical accounts in the chapters written by Voeks, Carney, Alpern, Bedigian, Rosengarten, Rasford, Sera \& Voeks, and Moret, and then integrated through theoretical and eco-botanical perspectives.

\section{References Cited}

Alexiades, Miguel ed. 2009 Mobility and Migration in Indigenous Amaronia: Contemporary Ethnoecological Perspectives. Studies in Environmental Anthropology and Ethnobiology Vol. 11. Berghahn Books, Oxford, U.K.

Howard, Patricia ed. 2003 Women and Plants: Gender Relations in Biodiversity Management and Conservation. Zed Books, London and New York. 